\title{
ОСОБЛИВОСТІ ТА ФОРМИ ОРГАНІЗАЦІї ЗАБЕЗПЕЧЕННЯ ГРОМАДСЬКОӤ БЕЗПЕКИ ЯК ФУНКЦІї УПРАВЛІННЯ У СФЕРІ ПРАВОПОРЯДКУ
}

\author{
СВДОКІМЕНКО Сергій Анатолійович - к.ю.Н., доценТ кафедри кримінально- \\ правових дисциплін та адміністративного права ТОВ «Харківський університет» \\ ORCID: 0000-0003-4700-9777 \\ DOI 10.32782/LAW.UA.2021.3.7
}

\begin{abstract}
В статье исследована суть организации обеспечения общественной безопасности. Освещено содержание понятия «организация» и его употребление в контексте управленческой деятельности. Проанализировань мнения ученых относительно организационных борм управления, а также их применение в деятельности правоохранительных органов. Изложено мнение относительно собственного видения организачии обеспечения общественной безопасности, как функиии управления в сфере правопорядка. Вълелено значение кадрового обеспечения правоохранительных органов, как организаиионной формы управления для формирования безопасновти в государстве. Установленъ основнве задачи кадрового обеспечения правоохранительньх органов, а также освещенъ теоретические и практические вопросъ, возникаюшие в данной сбере, предложенъ пути их решения. Раскрьто содержание информационного обеспечения правоохранительньхх органов, а также аргументировано необходимость его совершенствования. Исследована проблематика обмена информацией между государственными органами и организачиями, а также их подразделениями. Отмечена необходимость развития материально-технического обеспечения правоохранительных органов с иелью противостояния реальньл и потенииальнъим угрозам общественной безопасности.

Ключевъге слова: общественная безопасность, правоохранительньие органьи, организация, управление, инббормачионное обеспечение, кадровое обеспечение, материальное обеспечение, техническое обеспечение.
\end{abstract}

\section{Постановка проблеми}

Організація забезпечення громадської безпеки як вид управлінської діяльності представляе собою складний багаторівневий процес із розподілом функцій між суб’єктами іï забезпечення, їх взаємодії між собою. На теперішній час в Україні існує чимало невирішених завдань у цій сфері, вони стосуються як законодавчого закріплення організаційних питань, так і виконання їх на практиці.

\section{Аналіз останніх досліджень i}

$$
\text { публікацій }
$$

Бандурка О. М. надав загальну характеристику організаційним формам. Петров Г. І. визначив основні засади організаційних форм діяльності державного органу. Панова О. О. надала власне визначення «організаційним формам» забезпечення громадської безпеки. Кагановська Т. Є. висвітлила сутність кадрового забезпечення державних органів. Шатрава С. дослідив стан та правове регулювання кадрового забезпечення органів Національної поліції на сучасному етапі розвитку. Катеринчук I. П. дослідив актуальні питання інформаційного забезпечення правоохоронних органів України. Тесленко В. В. проаналізував поняття «фінансове забезпечення» та «матеріально-технічне забезпечення» правоохоронних органів. Бандурка О. М. визначив поняття матеріального, технічного та фінансового забезпечення правоохоронних органів, а також висвітлив 


\section{Адміністративне право}

питання психологічного забезпечення працівників правоохоронних органів.

\section{Не вирішені раніше частини загальної проблеми}

Зміни в державному управлінні, викликані децентралізацією державної влади, кризові ситуації, що виникли внаслідок дії зовнішніх факторів, потребують нових підходів до організації забезпечення громадської безпеки. Кадрове, інформаційне, матеріально-технічне забезпечення правоохоронних органів України залишається недосконалим, тому вказане питання потребує вирішення як на теоретичному, так і на практичному рівні.

Таким чином, метою дослідження $\mathbf{\epsilon}$ встановлення особливостей організації забезпечення громадської безпеки, як функції управління у сфері правопорядку, визначення основних форм такої організації.

\section{Виклад основного матеріалу}

Забезпечення громадської безпеки включає в себе як формування нормативноправової бази, так і виконання конкретної практичної діяльності суб'єктами забезпечення громадської безпеки. Одним із видів такої діяльності є організація забезпечення громадської безпеки, що виступає як функція управління у сфері правопорядку. Для повного розуміння сутності процесу організації забезпечення громадської безпеки необхідно встановити, що представляє собою поняття «організація» і як воно вживається як управлінська діяльність. Термін «організація» (від лат. «оrganum») означає інструмент, знаряддя. У сучасному ж значені поняття «організація» походить від франц. «organisation», що в буквальному перекладі означає упорядкування [1]. У сучасній українській мові слово «організація» використовують у декількох значеннях: дія за значенням організовувати, тобто забезпечувати, влаштовувати що-небудь, вишукуючи для цього необхідні можливості; чітко налагоджувати, належно впорядковувати що-небудь; комплекс заходів, зміст яких полягає в координації дій окремих елементів системи [2].
Для управлінської діяльності дослідження організації є цінним в основному 3 інструментальної точки зору, організацію описують як «функцію управління, яка полягає в призначенні завдань, виокремлення завдань для підрозділів і виділення ресурсів для їх виконання в підрозділах» [3]. Бандурка О. М. зазначив, що «організаційні форми не пов'язані зі здійсненням юридично значущих дій, а отже, не можуть спричиняти виникнення, зміну або припинення адміністративних правовідносин» [4, с. 308]. Організаційні форми «спрямовані на забезпечення належного й ефективного функціонування органів державної влади та посадових осіб, які здійснюють управлінську діяльність, за часом настання можуть або передувати, або наставати після реалізації правових форм державного управління. До неправових форм державного управління відносять різноманітні організаційні заходи, а також матеріально-технічні операції, що носять допоміжний характер, призначені обслуговувати всі інші форми управлінської діяльності й необхідні для одноразового врегулювання управлінських відносин [4].

Таким чином, організація забезпечення громадської безпеки, як функція управління, представляє собою застосування конкретних форм та методів управління 3 метою упорядкування діяльності суб'єктів забезпечення громадської безпеки, якісного виконання покладених на них завдань, належного формування і застосування законодавства з метою забезпечення громадського порядку і безпеки в державі. Організація забезпечення громадської безпеки, як функція управління, може здійснюватися шляхом кадрового забезпечення державних органів та організацій, що забезпечують громадську безпеку, інформаційного, матеріальнотехнічного, психологічного забезпечення. Варто зауважити, що хоча організація не передбачає безпосередній вплив на права i свободи людини і громадянина, проте неналежне здійснення уповноваженими органами, їх посадовими особами організаційних заходів із забезпечення громадської безпеки тягне за собою юридичну відповідальність, а дії таких посадових осіб визнаються неправомірними. Крім того, організація - такий 
складний механізм, у якому чітко розподілені права і обов'язки суб'єктів забезпечення громадської безпеки, вихід за межі повноважень $є$ порушенням законодавства і призводить до негативних наслідків і застосування засобів впливу з боку держави.

Зміни в державному управлінні, викликані децентралізацією державної влади, потребують нових підходів до формування кадрового апарату державних органів i структур, що забезпечують громадську безпеку (суб'єктів забезпечення громадської безпеки). Корупційна складова, що була присутня у підборі кандидатів на посади до вищезазначених органів та організації є значною перешкодою для побудови якісної системи забезпечення громадської безпеки. Більше того, законодавство, що регулює забезпечення громадської безпеки, побудоване таким чином, що існує дублювання повноважень державних органів і організацій. Такий стан законодавства є можливістю недобросовісного виконання обов'язків суб'єктами забезпечення громадської безпеки, а також вчинення корупційних дій.

Панова О. О. з цього приводу слушно зауважила, що основним завданням кадрового забезпечення публічної безпеки в Україні є планування комплексу заходів щодо формування якісного і кількісного складу працівників, спроможних ефективно виконувати свої функції, приймати обгрунтовані та неупереджені рішення. Вказані заходи мають бути спрямовані на упорядкування процедур підбору кадрів (у першу чергу, забезпечення дотримання принципу прозорості) та проходження служби; визначення професійних та особистісних якостей, яким повинен відповідати кандидат на виконання функцій у сфері забезпечення публічної безпеки; забезпечення ефективного функціонування системи підготовки майбутніх кандидатів на посади та підвищення кваліфікації осіб, що вже працюють; стимулювання керівників усіх рівнів до використання нового управлінського досвіду та впровадження сучасних методів мотивації; вироблення оновлених підходів оцінювання ефективності діяльності. Із вищевказаного можна зробити висновок, що кадрове забезпечення є основою для побудови функціонального держав- ного органу чи організації [5]. Перезавантаження правоохоронних органів, у тому числі Національної поліції України, було спрямоване на повне оновлення їх кадрового апарату, у тому числі апарату управління. Проте не було враховано необхідність попередньої якісної підготовки майбутніх працівників правоохоронних органів, забезпечення їх належною освітою, а також практичною, психологічною підготовкою. Склалася ситуація, за якої бажання новообраних працівників не співпадало 3 їх реальними можливостями протидіяти високому рівню злочинності. У зв'язку з чим вважаємо за потрібне збільшити інтервал навчання майбутніх працівників правоохоронних органів у вищих навчальних закладах. Позитивним слід відмітити обмін досвідом із представниками правоохоронних органів іноземних держав. Так, до проєктів внесення змін до нормативно-правової бази і практичної діяльності підрозділів Національної поліції залучалися іноземні фахівці, проте слід було 6 прийняти до уваги умови економічного, соціального, культурного розвитку держави тощо, а також врахувати стан законодавства i комплексно підійти до зміни законодавчої бази правоохоронних органів. Колізії i неточності в деяких нормативно-правових актах, що регулюють забезпечення громадської безпеки і на теперішній час формують ситуацію, за якої виникають складнощі на практиці.

Розвиток інформаційних технологій, у тому числі активне використання соціальних мереж, застосування можливостей таких технологій злочинними, у тому числі терористичними організаціями, створює необхідність адекватного інформаційного забезпечення суб'єктів забезпечення громадської безпеки. Поняття «інформаційне забезпечення» та категорії «інформаційне забезпечення управління» досить грунтовно розглянуто в монографії за редакцією P. А. Калюжного та В. О. Шамрая. Вони виділяють три основні значення поняття «інформаційне забезпечення»: а) забезпеченість системи управління відповідною множиною інформації; б) діяльність, пов'язана 3 організацією збору, реєстрації, передачі, зберігання, опрацювання і представлення 


\section{Адміністративне право}

інформації; в) діяльність щодо формування цілеспрямованої суспільної й індивідуальної свідомості суб’єктів суспільних відносин щодо управління в конкретній сфері суспільних відносин (у сучасній літературі ця сутність визначається такими категоріями, як реклама, паблік-рілейшин, формування суспільного іміджу суб'єкта управління, інформаційні операції, інформаційна боротьба, пропаганда і контрпропаганда та ін.) [6].

3 точки зору управління персоналом інформаційне забезпечення - це отримання всієї можливої інформації про потенціал та побажання працівників, збір інформації про особливості робочого місця та робочого колективу, формалізація інформації з метою можливості іiі зіставлення і перевірки, виявлення якостей, виявлення стану ринку освітніх послуг і можливостей, а також умов отримання послуг, пов'язаних 3 розвитком персоналу [7, с. 67].

На думку автора дослідження в контексті забезпечення громадської безпеки інформаційне забезпечення представляє собою: 1) збір, обробку, використання інформації, що має значення для забезпечення громадської безпеки, в тому числі інформації з обмеженим доступом; 2) накопичення попередньо отриманої інформації шляхом формування баз даних; 3) обмін інформацією між суб'єктами забезпечення громадської безпеки, що здійснюється в рамках законодавства, за заздалегідь розробленими правилами; 4) використання інформації, здобутої в результаті застосування інформаційних технологій, в тому числі соціальних мереж, веб-сайтів тощо, 3 метою забезпечення громадської безпеки (розслідування кримінальних правопорушень, профілактичної діяльності та ін.); 5) висвітлення інформації публічного значення на офіційних веб-порталах територіальних підрозділів органів та організацій, що забезпечують громадську безпеку. Повідомлення громадськості про події, заходи, що стосуються забезпечення громадської безпеки має велике значення для організації діяльності у вказаній сфері, оскільки громадськість також виступає суб'єктом забезпечення громадської безпеки і все частіше представники громадськості залучаються до безпосереднього процесу охорони громадського порядку і забезпечення безпеки.

Зауважимо про відсутність згадувань інформаційного забезпечення правоохоронних органів у базових законодавчих актах, які регулюють їх діяльність та відсутність системності у прийнятті відповідних законів, відомчих нормативно-правових актах. Отже, сьогодні набуває актуальності здійснення системного аналізу та вдосконалення нормативно-правової бази інформаційного забезпечення у сфері правоохоронної діяльності.

Матеріально-технічне забезпечення визначає можливості суб'єктів забезпечення громадської безпеки адекватно протидіяти загрозам громадській безпеці. За наявності відповідних матеріальних ресурсів, а також технічних засобів стає можливим профілактика таким загрозам. Бандурка О. М. під матеріальним, технічним та фінансовим забезпеченням запропонував розуміти систему товарно-грошових і господарських відносин, які виникають між службами МВС, органами влади, підприемствами, організаціями, фізичними особами, з одного боку, та органами системи MBC, з іншого, у процесі централізованого постачання матеріальних, технічних і військових ресурсів (сировина, паливо, обладнання, речове майно, зброя, боєприпаси і матеріали); виконання договорів купівлі-продажу (оптова торгівля), реалізації фондів, комісійного й роздрібного продажу продуктів і засобів виробництва; надання матеріально-технічної допомоги та фінансування їх діяльності [8, с. 17].

Виходячи із законодавства України, під матеріально-технічним забезпеченням поліції слід розуміти систему товарно-грошових i господарських відносин, які виникають між органами державної влади, органами системи МВС, підприємствами, організаціями, фізичними особами, з одного боку, та підрозділами поліції, з іншого, у процесі постачання матеріальних, технічних і військових ресурсів для задоволення потреб, необхідних для виконання основних обов'язків i завдань, передбачених статтею 2 Закону України «Про Національну поліцію» [9].

Окремої уваги заслуговує значення технічного забезпечення правоохоронних ор- 
ганів, оскільки такі технічні засоби мають свою специфіку як щодо їх характеристик, так і щодо сфери застосування. Крім того, застосування технічних засобів з метою забезпечення громадської безпеки потребує спеціальних умінь і навичок суб'єктів, які їі застосовують. Якісні зміни арсеналу науково-технічних засобів, що відбулися останніми роками під впливом науково-технічного прогресу, відкрили нові можливості в роботі з інформацією, поставили перед криміналістикою та кримінальним процесом завдання вдосконалювання старих і розроблення нових методик іiі опрацювання. Досить перспективними для використання в практиці правоохоронців є комп'ютерні технології. Вони дозволяють фіксувати й опрацьовувати інформацію в найкоротші терміни, уникаючи складних лабораторних процесів. Застосування технічних засобів при забезпеченні громадської здійснюється лише за встановленими законодавством нормами і правилами, жодних відхилень від таких норм бути не може, інакше їх застосування буде не ефективним і не правомірним, а отже - порушуватиме права і свободи людини і громадянина.

\section{Висновки}

Як показує практика, підвищення замаскованості та професіоналізму дій злочинців у сучасний період, поява нових видів злочинів потребують адекватних заходів протидії [10, с. 394, 395]. Організація забезпечення громадської безпеки як вид управлінської діяльності представляє собою складний багаторівневий процес із розподілом функцій між суб'єктами ії забезпечення, їх взаємодії між собою. На теперішній час в Україні існує чимало невирішених завдань у цій сфеpi, вони стосуються як законодавчого закріплення організаційних питань, так і виконання їх на практиці. Нерідко конкретні питання забезпечення громадської безпеки вирішуються стихійно, без заздалегідь сформованих планів, не приймаючи до уваги наявні та необхідні матеріальні і технічні ресурси тощо. Через що не вдається отримати очікувані результати роботи, затрачені сили i засоби не виправдовуються. Підходи до організації забезпечення громадської без- пеки повинні постійно удосконалюватися, розвиватися, адже від цього залежить формування середовища безпеки у державі.

\section{Література}

1. Великий енциклопедичний юридичний словник / за ред. Ю. С. Шемшученка. Київ : Юридична думка, 2007. С. 569.

2. Великий тлумачний словник сучасної української мови / уклад. і голов. ред. В.Т. Бусел. Київ ; Ірпінь : ВТФ «Перун», 2009. С. 853; Прокопенко О. Ю. Поняття організаційних форм діяльності органів внутрішніх справ як суб'єкта забезпечення правопорядку в регіоні. Науковий вісник Ужгородського нац. ун-ту. Сер.: Право. 2015. Вип. 35 (1.3). С. 10.

3. Відомості 3 інтернет-ресурсу [Електронний ресурс]. - Режим доступу: https:// uk.wikipedia.org/wiki/\%D0\%9E\%D1\%80\%D0\% B3\%D0\%B0\%D0\%BD\%D $1 \% 96 \%$ D0\%B 7\%D0 $\% \mathrm{~B} 0 \% \mathrm{D} 1 \% 86 \% \mathrm{D} 1 \% 96 \% \mathrm{D} 1 \% 8 \mathrm{~F}$

4. Адміністративне право України. Загальна частина. Академічний курс : підруч. / за заг. ред. акад. НАПрН України О. М. Бандурки. Харків : Золота миля, 2011.

5. Панова О.О. Забезпечення публічної безпеки в Україні: адміністративноправовий аспект : монографія. - Харків : Панов. 2018. - 510 с.

6. Інформаційне забезпечення управлінської діяльності в умовах інформатизації: організаційно-правові питання теоpiï i практики: моногр. / Калюжний Р. А., Шамрай В. О., Швець М. Я. та ін.] / за редР. А. Калюжного та В. О. Шамрая. К., 2002. С. 39; Адміністративне право України. Академічний курс : підручник: у 2 т. Т. 1: Загальна частина / ред. кол.: В. Б. Авер'янов (голова). К. : Юрид. думка, 2004. 584 с.

7. Спивак В. А. Развивающее управление персоналом. / В. А. Спивак СПб. : Издат. Дом «Нева», 2004. - 440 с.

8. Бандурка О.М. Теорія і практика управління органами внутрішніх справ України : монографія. Харків, 2004.

9. Про Національну поліцію: закон України від 2 липня 2015 року № 580-VIII [Електронний ресурс]. - Режим доступу: https://zakon.rada.gov.ua/laws/show/58019\#Text 


\section{Адміністративне право}

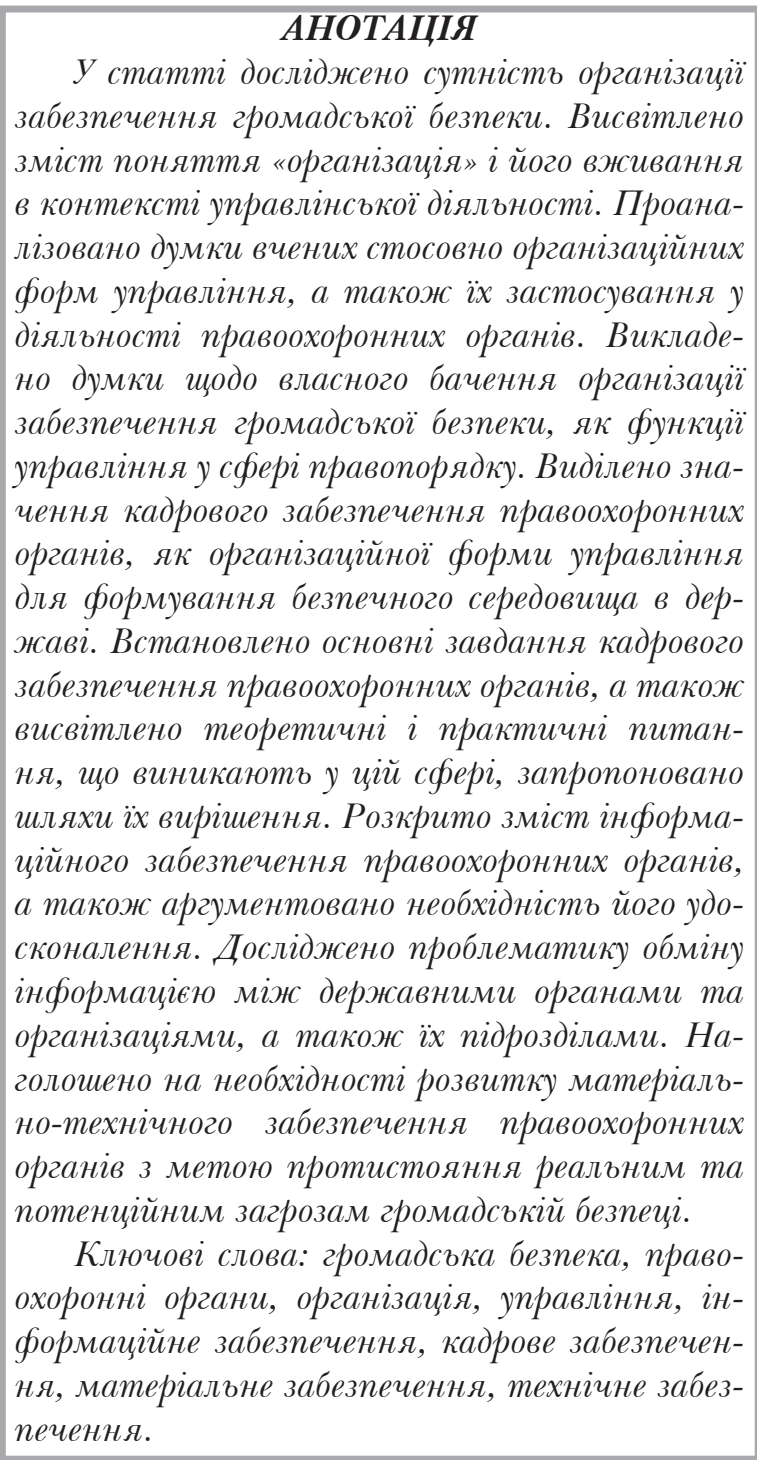

10. Теория оперативно-розыскной деятельности: Учебник / Под редакцией К.К. Горяинова, В.С. Овчинского, Г.К. Синилова. - М.: ИНФРА - М, 2010. - Х, 831 с. (Высшее образование).

\section{SPECIFIC FEATURES AND FORMS OF ENSURING PUBLIC SAFETY AS MANAGEMENT FUNCTION IN THE LAW ENFORCEMENT SECTOR}

The essence of the organization of ensuring public safety has been studied in the article. The content of the concept of "organization" and its application in the context of management activity has been highlighted. The opinions of scholars in regard to organizational forms of management, as well as their application in the activities of law enforcement agencies have been analyzed. The author has presented own opinions on the organization of ensuring public safety as a management function in the law enforcement sector. The importance of law enforcement agencies' staffing as an organizational form of management for the formation of a safe environment in the state has been distinguished. The main tasks of staffing of law enforcement agencies have been established; and theoretical and practical issues arising in the given sphere have been covered; the ways of their solution have been offered. The content of information support of law enforcement agencies has been revealed, and the necessity of its improvement has been argued. The problems of information exchange between state agencies and organizations, as well as their subdivisions have been studied. The author has emphasized on the need to develop logistics of law enforcement agencies in order to counter real and potential threats to public safety.

Key words: public order, law enforcement agencies, organization, management, information support, staffing, tangible security, technical support. 